\title{
Seroprevalence of Bovine Brucellosis and Associated Risk Factors in Western Ethiopia
}

\author{
Demiso Merga Sima' \\ Debela Abdeta Ifa $\mathbb{D}^{\prime}$ \\ Akililu Likasa Merga ${ }^{2}$ \\ Eyob Hirpa Tola (1D) \\ 'Wollega University, College of \\ Veterinary Medicine, Nekemte, Ethiopia; \\ ${ }^{2}$ West Wollega Zone, Haru District \\ Livestock and Fishery Development \\ Office, Gimbi, Ethiopia
}

Background: Brucellosis is a contagious bacterial disease, which affects domestic animals, humans, and wildlife in Ethiopia and other countries.

Methods: A cross-sectional study design using a simple random sampling technique was conducted in Diga, Guto, Gida, and Sibu Sire districts of East Wollega Zone, Western Oromia, from November 2019 to July 2020 to determine the prevalence of bovine brucellosis and identify associated risk factors. A lottery method was used during serum collection and risk factors identified during interview.

Results: A total of 1152 serum samples were collected from cattle of 6 months age and above. Serum samples were tested by enzyme linked immunosorbent assay (I-ELISA). An overall seroprevalence of brucellosis was $1.82 \%$ (21/1152). Statically significant variation $(P<0.05)$ in seroprevalence of bovine brucellosis was recorded among potential risk factors such as breed $[P \leq 0.05$; OR:8.905; CI:1.568-50.573], parity [ $P \leq 0.05$; OR:0.017; CI:0.0425.195], retained fetal membrane [ $P \leq 0.001$; OR:0.018; CI:0.00-2.169], and abortion history

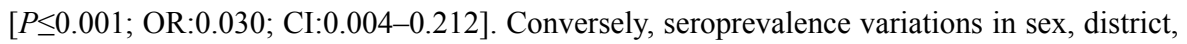
villages, body condition score, and age were statistically insignificant $(P>0.05)$.

Conclusion: The current study revealed bovine brucellosis is posing a threat to livestock with no strict control and prevention scheme in place. Therefore, public awareness creation about the zoonotic importance of the disease is crucial and the Government should establish legislation, support, control, and prevention of the disease recommended.

Keywords: bovine brucellosis, Brucella, districts, ELISA, risk factors, seroprevalence, serum

\section{Introduction}

Brucellosis is a highly contagious, zoonotic, and economically important bacterial disease of wide variety of terrestrial and aquatic animals. This disease is considered one the most widespread world's zoonosis. ${ }^{1}$ Domestic animals (cattle, sheep, goats, camels, and pigs), humans, and wildlife are affected by this disease. ${ }^{2}$ There are usually three main causes of bovine brucellosis namely Brucella abortus, B. melites and B. suis. ${ }^{3}$ Brucella abortus serovar-1 is the common serovar. ${ }^{4,5}$ Third trimester abortion, weak calves, stillbirth, endometritis, infertility, and reduced milk production are common signs in female animals. In bulls the disease is characterized by orchitic, epidydimitis, seminal vasculitis, and sterility. ${ }^{6,7}$ Since brucellosis is an important cause of abortion, especially in first calf heifer, the disease can also cause economic losses in developing countries. ${ }^{3}$ Ingestions of contaminated pasture, feed, fodder, water and contact with aborted fetus, urine discharge, and new born calves which contains a large dose of infectious organisms constitute a very important
Correspondence: Eyob Hirpa Tola Email eyobh@wollegauniversity.edu.et; eyobhirpatola@gmail.com 
source of infection. ${ }^{44}$ The risk factors that influence transmission and maintenance of brucellosis were age, sex, number of parity, and number of service; preconception and reproductive status were associated with seropositivity of Brucella species. ${ }^{1}$

Despite the contribution of the livestock sector in Ethiopia to the national economy, the productivity per animal is very low, primarily due to technical constraints and diseases like brucellosis. ${ }^{8}$ A large number studies on cattle have reported seroprevalence of brucellosis ranging from $0-50 \%$ in intensive management systems ${ }^{9,10}$ and $0.05-15.2$ in extensive management systems. ${ }^{11,12}$ Human and animal brucellosis were reported from different localities of Ethiopia in particular which is associated with cattle in different agro-ecology and production systems. ${ }^{13}$ The prevalence studies in animals and humans are largely confined to serological surveys and commonly targeted bovine brucellosis, occasionally sheep and goat, and rarely camel. Therefore, so far an attempt to identify Brucella species in the country was unsuccessful; the distribution and proportion of their natural host have also not been exhaustively studied. ${ }^{14}$ The prevalence of bovine brucellosis is established in different parts of the country, but little information is available on its status in the study area. Further assessment on the status of the disease and associated risk factors has paramount importance for control and prevention of brucellosis in Ethiopia in general and western Ethiopia in particular. Hence the current study aimed to determine seroprevalence of bovine brucellosis in the study area, as well as the risk factors involved.

\section{Materials and Methods}

\section{Description of the Study Area}

The study was conducted in three purposively districts of East Wollega Zone Western Oromia, Ethiopia, namely: Diga, Guto Gida, and Sibu Sire districts based on accessibility to the road, feasibility of sample collection, and number of cattle they possess. Diga district is located at a distance of $343 \mathrm{~km}$ from Addis Ababa and $12 \mathrm{~km}$ from Nekemte. There are about 69,965 cattle, 16,424 ovine, 11,857 caprine, 39,730 poultry, and 80,099 people. Its potential land area coverage is $59,545.43$ hectares. It is bounded by East Guto Gida, West Wollega Zone and Benishangul Gumuz, North Sasiga district, and South Leka Dulecha, as reported by Diga Livestock and Fishery Office. ${ }^{16}$ Guto Gida districts are located at a distance of $320 \mathrm{~km}$ south west of Addis Ababa, the capital city of Ethiopia. There are about 13,6005 cattle, 22,004 ovine, 23,349 caprine, 837,095 poultry, and 101,189 human population. It is bounded by East Wayu Tuka, West Diga and Sasiga districts, North Gida Ayana district, and South Leka Dulecha. ${ }^{17}$ Sibu-Sire district is located at a distance of $273 \mathrm{~km}$ west of Addis Ababa and $58 \mathrm{~km}$ from Nekemte. There are about 323,954 cattle, 45,723 ovine, 32,258 caprine, 186,215 poultry, and 92,099 human populations. A map of the study area is indicated in Figure 1.

\section{Study Population}

The inclusion criteria of the study population were cattle with the age of 6 months or above and both indigenous breeds of cattle kept under extensive husbandry and crossbreeds in the selected sites of Diga Guto Gida, and Sibu Sire districts were the study subject. Accordingly, by guidance of development workers 384 heads of cattle of age greater than 6 months and both sex were sampled from three selected PAs of each district. The animals were sampled from each PA by including different households and proportionally selecting from their cattle by lottery method. During sampling most of the animals included in the study were female animals since they were kept for milk and production where males sent for draught and slaughtering purposes. ${ }^{54,55}$

\section{Study Design}

A cross-sectional study was used to screen for bovine brucellosis between November 2019 to July 2020 .

\section{Sampling Technique and Sample Size Determination}

The total number of animals required was determined using the formula given by Thrusfield. ${ }^{18}$ Sample size was determined by using the $95 \%$ confidence interval at $50 \%$ expected prevalence and 0.05 desired absolute precision.

Therefore,

$n=\frac{((1.96) 2(\operatorname{Pexp})(1-\text { pexp }))}{d^{2}}=384$. To increase the precision, three fold of the sample were included from different agroecology.

Where $n=$ required sample size; $p \exp =$ expected prevalence, $d=$ desired absolute precision.

Studied animals were selected by simple random sampling technique. Accordingly, 1152 heads of cattle of both sexes and different age groups were included in this study. Numbers of samples for each district and village are indicated in Figure 2. 


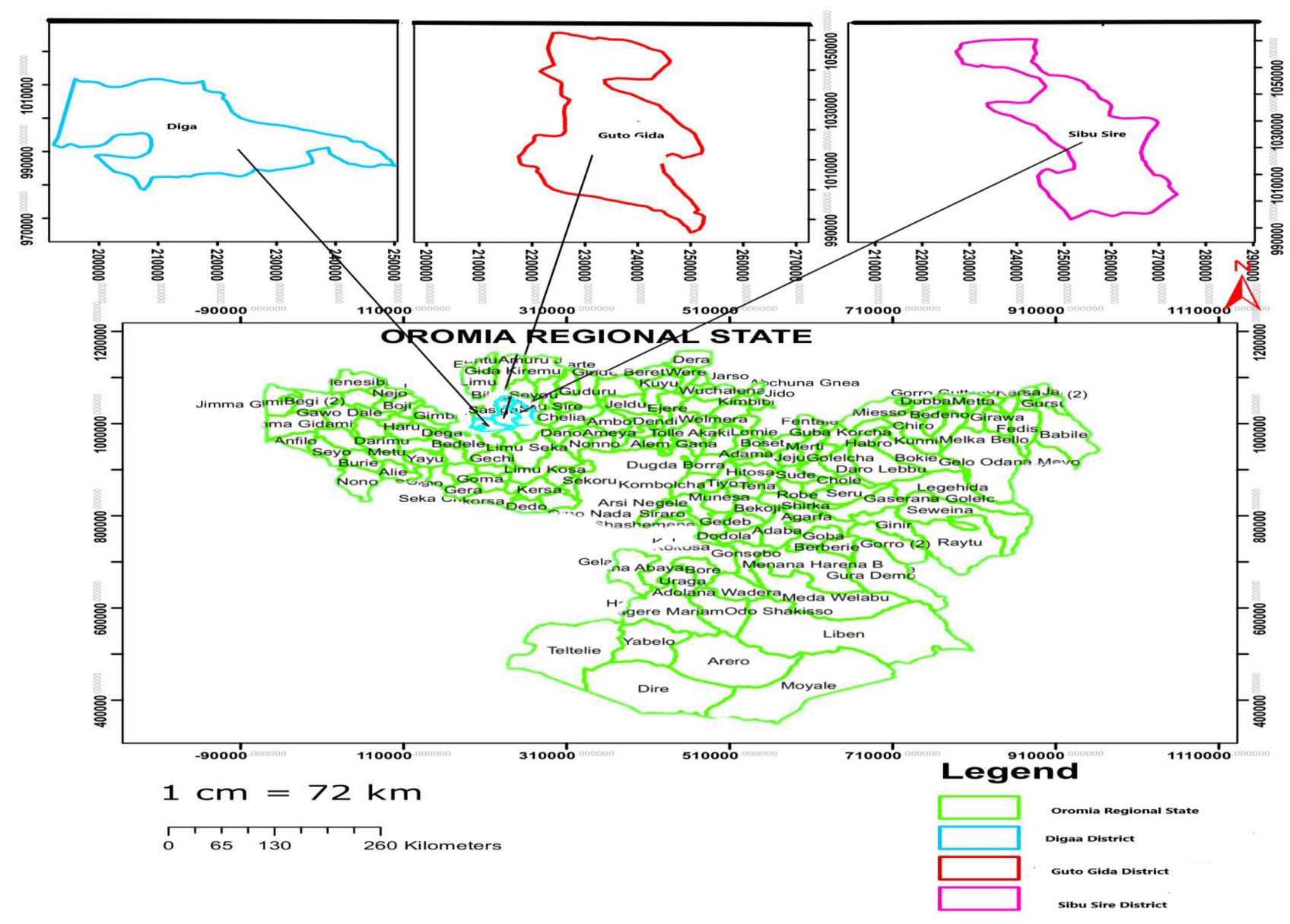

Figure I Map of study area.

\section{Blood Sample Collection and Transportation}

Blood sample $(9 \mathrm{~mL})$ was collected from the jugular vein of each animal using sterile needles and plain vacutainer tube and allowed to clot in a slant position at room temperature. The serum was decanted into a labeled vial and stored at $-20{ }^{\circ} \mathrm{C}$ until transported. ${ }^{19}$ The sera were transported to Bedele regional laboratory center (BRLC), bacteriology/serology unit, by using an ice box and stored at $-20{ }^{\circ} \mathrm{C}$ for further processing. ${ }^{20}$ Breed, sex, age, body condition, and peasant associations with other risk factors were recorded along with each animal blood sample.

\section{Indirect Enzyme Linked Immunosorbent Assay}

All collected sera were screened by indirect enzyme linked immunosorbent assay (I-ELISA) according to the World Organization for Animal Health ${ }^{20}$ procedures and instructions. Indirect enzyme linked immunosorbent assay was performed using a commercial I-ELISA kit (from ID.vet, BRUS-MS-5P, C35, 1014GB, Grabels, France). It detects antibody directed against $B$. abortus. The protocol provided by developers was followed. ${ }^{20}$ Before performing the test the serum and all reagents were taken out of the refrigerator and left half an hour at room temperature. The serum and controls were added in to the microwells, which were coated with $B$. abortus LPS at $1 / 20$ dilution rate. Following the addition of multispecies horseradish peroxidase (HRP) conjugate and substrate solution (TMB) at a recommended strength, the plate strength, the plate incubated, and examined for the intensity of reaction on automated ELISA reader at $450 \mathrm{~nm}$. Yellow color developed within a well after dilution of stop dilution indicates that the tested serum has antibodies to Brucella. The test was valid if the mean odds ratio value of positive and the ratio of positive to negative control were calculated as ODPC $>1.0$ and ODPC/ODNC $>0.1$ respectively. The result harvested was interpreted as seropositivity percentage ( $\mathrm{S} / \mathrm{P}$ $\%$ ) of $\geq 60 \%$ as positive and $<60 \%$ as negative. ${ }^{20}$ 


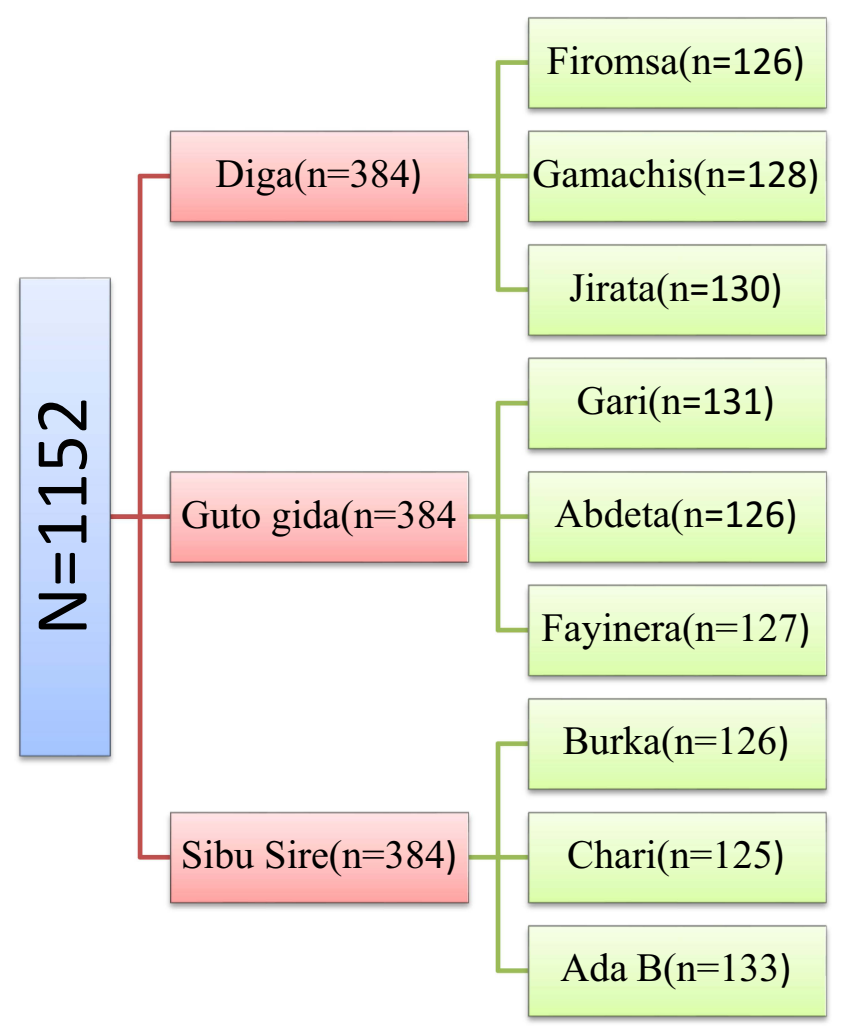

Figure 2 Sample size of each district and each village.

\section{Data Management and Analysis}

Data entered on Microsoft Excel spreadsheet were analyzed using STATA version 14. Multivariate logistic regression was used to test the significance effect of risk factors. Odds ratio (OR) was utilized to measure the degree of association between risk factors and brucellosis. For statistical inference $P$-value $<0.05$ at $95 \%$ confidence level and $5 \%$ precision was considered as statistically significance.

\section{Ethical Approval and Consent to Participate}

All participants were informed about the purpose of this study and signed written legal consent for participation prior to the commencement of the study. Study design involves animals for blood sample and human participants for interview. The Survey protocol and animal handling ethics was approved by Wollega University School of Veterinary Medicine Ethical Review Board. Support letters were also, granted from East Wollega Zone, Livestock and Fishery resource office, and the administration Office of East Wollega Zone.

\section{Results}

\section{SeroPrevalence of Bovine Brucellosis}

From the total of 1152 bovine sera collected, overall seroprevalence of brucellosis $1.82 \%(21 / 1152)$ was recorded. An almost similar finding was recorded in Guto Gida and Sibu Sire districts, 2.08\% (8/384) and $2.34 \%$ (9/384), respectively. Lower $1.04 \%$ (4/384) seroprevalence reported in Diga District, specifically Jirata village, was reported zero free of brucellosis. However, the prevalence variations among districts were statistically insignificant $(P>0.05)$ (Table 1).

\section{Association of Potential Risk Factors with Seroprevalence of Bovine Brucellosis}

According to the present study, higher anti-Brucella antibody was detected in female than male studied animals, which was $2.3 \%$ and $0.6 \%$, respectively. However, the variation was statistically not significant $(p>0.05)$.

Table I Seroprevalence of Bovine Brucellosis in Three Different Districts of East Wollega Zone

\begin{tabular}{|c|c|c|c|c|c|c|c|c|}
\hline District & Village & Tested & Negative & Positive & $\begin{array}{c}\text { Village Level } \\
\text { Prevalence }\end{array}$ & $\begin{array}{l}\text { District Level } \\
\text { Prevalence }\end{array}$ & $P$-value & Odds Ratio [95\% Cl] \\
\hline \multirow[t]{3}{*}{ Diga } & Firomsa & 126 & 123 & 3 & 2.4 & 1.04 & 0.669 & \\
\hline & Gemechis & 128 & 127 & I & 0.8 & & & \\
\hline & Jirata & 130 & 130 & 0 & 0 & & & \\
\hline \multirow[t]{3}{*}{ Guto Gida } & Gari & 126 & 122 & 4 & 3.2 & 2.08 & 0.996 & $0.000[0.000-10.00]$ \\
\hline & Abdeta & 131 & 130 & I & 0.8 & & & \\
\hline & Fayinera & 127 & 124 & 3 & 2.36 & & & \\
\hline \multirow[t]{3}{*}{ Sibu Sire } & Burka Talo & 129 & 126 & 3 & 2.3 & 2.34 & 0.370 & $3.009[0.27 \mid-33.393]$ \\
\hline & Chari Jarso & 130 & 125 & 5 & 3.8 & & & \\
\hline & Ada Buke & 125 & 124 & I & 0.8 & & & \\
\hline \multicolumn{2}{|c|}{ Total prevalence } & 1152 & $|13|$ & 21 & & 1.82 & & \\
\hline
\end{tabular}


Table 2 Step Wise Association of Risk Factors with Seropositivity of Bovine Brucellosis

\begin{tabular}{|c|c|c|c|c|c|c|}
\hline Factors & Variables & $\begin{array}{l}\text { Tested } \\
\text { Animal }\end{array}$ & Positive & Seropositivity & $P$-value & Odds ratio $[95 \% \mathrm{Cl}]$ \\
\hline \multirow[t]{2}{*}{ Breed } & Cross & 27 & 2 & 7.4 & & \\
\hline & Local & 1125 & 19 & 1.7 & 0.014 & $8.905[1.568-50.573]$ \\
\hline \multirow[t]{2}{*}{ Sex } & Male & 336 & 2 & 0.6 & & \\
\hline & Female & 816 & 19 & 2.3 & 0.166 & $2.966[0.638-13.794]$ \\
\hline \multirow[t]{3}{*}{ Age } & $\begin{array}{l}6 \\
\text { months-3 years }\end{array}$ & 240 & 2 & 0.8 & & \\
\hline & $3-6$ years & 622 & 12 & 1.9 & 0.358 & $0.307[0.056-1.668]$ \\
\hline & 6 years & 290 & 7 & 2.4 & 0.171 & $0.523[0.147-1.862]$ \\
\hline \multirow[t]{3}{*}{ BCS } & Poor & 375 & 15 & 4 & & \\
\hline & Medium & 635 & 4 & 0.6 & 0.118 & $3.550[0.725-17.375]$ \\
\hline & Good & 140 & 2 & 1.4 & 0.348 & $0.428[0.073-2.518]$ \\
\hline Retention of placenta (only & Present & 60 & 13 & 21.66 & & \\
\hline female) & Absent & 756 & 6 & 0.79 & $\leq 0.001$ & $0.018[0.002-0.169]$ \\
\hline Abortion history (only & Absent & 745 & 7 & 0.94 & & \\
\hline female) & Present & 71 & 12 & 8.7 & $\leq 0.001$ & $0.030[0.004-0.212]$ \\
\hline \multirow[t]{3}{*}{ Parity (only female) } & No parity & 359 & 5 & 1.39 & & \\
\hline & Single parity & 92 & 2 & 2.17 & 0.040 & $27.372[1.158-646.908]$ \\
\hline & Multiple parity & 365 & 12 & 3.29 & 0.045 & $0.017[0.042-5.195]$ \\
\hline \multirow[t]{2}{*}{ Pregnant status (only female) } & Not Pregnant & 542 & 6 & 1.11 & & \\
\hline & Pregnant & 274 & 13 & 4.66 & 0.633 & $0.566[0.055-5.831]$ \\
\hline
\end{tabular}

Similarly, seroprevalence variations in district, villages, breed, age, and body condition score were statistically non-significant $(p>0.05)$ (Table 2). On the other side, other variables, breed, pregnancy status, retained fetal membrane, and abortion history were significantly associated with the disease $(P<0.05)$ (Table 2$)$.

The results of univariable analysis indicated that there is a significant association between the local and crossbreeds of female cattle and Brucella seroprevalence. The odds of bovine brucellosis in the crossbreed are 8.905 (95\% CI:1.568-50.573) times higher than those of the local breed. Similarly, history of abortion and placental retention in females was found to be significantly associated with bovine brucellosis. Univariable logistic regression revealed that cattle with a history of abortion had 0.03 times (95\% CI:0.004-0.212) odds than female cattle with no history of abortion. The odds of cattle with single parity were 27.372 times higher than no parity whereas cattle with multiple parity were 0.017 times higher than that of no parity (Table 2).

\section{Discussion}

Bovine brucellosis remains largely underdiagnosed and uncontrolled amongst many pastoral peoples and small scale livestock holders. Scarcity of resources combined with problem in diagnosis of the disease, limited knowledge of regional epidemiology, and little understanding of the social factors contributing to the disease increases the persistence of the disease in bovine population in Diga, Guto Gida and Sibu Sire Districts of East Wollega Zone. ${ }^{14}$ The overall prevalence of brucellosis in the western part of Ethiopia was $1.82 \%$. This finding was comparable with previous recorded reports from different parts of Ethiopia, ${ }^{21}$ such as $1.3 \%$ in Eastern Ethiopia, ${ }^{22} 1.38$ in Somali Regional state, Jijjiga Zone, ${ }^{4,15} 1.4 \%$ in Bushoftu and Asella, ${ }^{23} 1.49 \%$ in North West Ethiopia and ${ }^{56} 1.04 \%$ seroprevalence of bovine brucellosis recorded by I- ELISA technique in in Becho District, South West Shewa, Oromia Regional State, Ethiopia.

On the other side, lower seroprevalence was recorded in different parts of Ethiopia, ${ }^{11}$ with $0.73 \%$ in Jimma Zone, ${ }^{24} 0.49 \%$ in Western Shewa, ${ }^{25} 0.4 \%$ in urban dairy farms of Northern Ethiopia, ${ }^{26} 0.2 \%$ in Debrebirhan and Ambo Towns, ${ }^{12}$ and with $0.05 \%$ in Arsi Zone. There are reports of a higher seroprevalence rate of bovine brucellosis in other parts of the country, ${ }^{27} 3.1 \%$ in Jimma Zone of Oromia region, ${ }^{28} 2.77 \%$ in the Addis Ababa dairy cattle, ${ }^{29} 4.3 \%$ in Adami Tulu, central Ethiopia, ${ }^{30} 4.9 \%$ in 
Western Tigray, ${ }^{3} 8.0 \%$ in pastoral region of the country, ${ }^{31}$ $9.87 \%$ in Asella organized dairy farm, ${ }^{32} 10.6 \%$ in Borana, ${ }^{33} 11.0 \%$ in Wuchale-Jida district, central Ethiopia, ${ }^{34}$ and with $11.2 \%$ in pastoral and agro-pastoral areas of East Shewa Zone. Similarly, higher seroprevalence was reported in other African countries ${ }^{35}$ with $5.3 \%$ in Tanzania, ${ }^{36} 24.0 \%$ in Nigeria, ${ }^{37} 21.9 \%$ in Ghana ${ }^{38}$ and $24.5 \%$ in Sudan. The difference in total prevalence may be due to the difference in study season, type of production system, differences in sample size, laboratory techniques employed, and ecology.

Prevalence in cross-bred (7.4\%) animals was higher than in local $(1.7 \%)$ cattle. This difference was statistically significant $(p<0.05){ }^{31,39-42}$ There was similarly reported significant variation in the serological prevalence of brucellosis with the prevalence in cross-bred than indigenous ones. The higher seroprevalence in crossbreeds might be due to the lower sample size, the smaller number of the crossbreeds examined compared to local breeds.

In the present study, sex was one of the risk factors affecting the susceptibility of cattle to the Brucella infection. Seropositivity in females $(2.32 \%)$ was indicated in the study area whereas $(0.6 \%)$ seropositive in males. However, the finding was statistically insignificant which disagrees with the previous report. ${ }^{11,43}$ The lower seroprevalence in males could be due to smaller number of males examined when compared to females and it was also reported that the serological response of male animals to Brucella infection is limited. ${ }^{44,45}$ In addition to this, it has also been reported that infected male animals are usually found to show low antibody titers. ${ }^{46}$

It is obvious that sexually matured animals are more susceptible to B. abortus infection, ${ }^{11,45}$ which was explained by the fact that susceptibility increases during sexual maturity and gestation period due to the influence of sex hormones and elevation of fetal fluid and erythritol sugar in the placenta. This stimulates the growth and multiplication of bacteria in the reproductive organs. ${ }^{1,30,47}$ However, in the current finding, seroprevalence variations among groups of ages are statistically insignificant.

In present study, the association of parity and Brucella infection was statistically significant. Different findings were reported. $^{45,49}$ The existence of abortion history and retained fetal membrane were significantly associated $(p<0.05)$ with the infection in this study. This finding was consistent with the Tolosa and Geresu. ${ }^{48,49}$ This could be explained by the fact that these two factors are the typical outcome of the brucellosis. ${ }^{31,41,49}$ Other studies have also shown a significant association between the disease and abortion and retained fetal. ${ }^{27,41,43,50}$ Similarly, studies from different African countries show that brucellosis in bovine directly correlates with the presence of abortion. ${ }^{51-53}$

\section{Conclusion and Recommendations}

The present study revealed that the overall prevalence of bovine brucellosis in the study area was 1.82 . Sex, BCS, breed, retained fetal membrane, and abortion history were potential risk factors for the studied disease. But, there is no control and prevention scheme in place because of lack of information on the disease status and the cost of elimination of the disease from the country is far beyond the economic status of the farmers and the country at large. Therefore;

- Awareness creation about the impact of the disease, the way of its transmission, risk factors, methods of prevention of the disease, and culling of the positive animals should be made.

- Proper hygienic and sanitation practices to reduce the risk of exposure to brucellosis.

- Furthermore, detailed study to investigate the link of the disease with human in the study area was recommended.

\section{Acknowledgments}

The author acknowledges Bedele Regional Veterinary Laboratory staff for their support and collaboration during sample collection and processing. Moreover, I would like to acknowledge the Diga, Guto Gida, and Sibu Sire Districts, Livestock and Fishery resource development office, and agents for their help during field data collection through facilitating technical work and coordination of farmers.

\section{Funding}

The study funded supported by Wollega University and Bedele Regional veterinary laboratory.

\section{Disclosure}

The authors report no conflicts of interest in this work.

\section{References}

1. Asgedom H, Damena D, Duguma R. Seroprevalence of bovine brucellosis and associated risk factors in and around Alage district, Ethiopia. Springer Plus. 2016;5(1):851. doi:10.1186/s40064-0162547-0 
2. Geresu MA, Ameni G, Tuli G, Arenas A, Kassa GM. Seropositivity and risk factors for Brucella in dairy cows in Asella and Bishoftu towns, Oromia Regional State, Ethiopia. Afr J Microbiol Res. 2016;10(7):203-213. doi:10.5897/AJMR2015.7707

3. Megersa B, Biffa D, Abunna F, Regassa A, Godfroid J, Skjerve E. Seroepidemiological study of livestock brucellosis in a pastoral region. Epidemiol Infect. 2012;140(5):887-896. doi:10.1017/ S0950268811001178

4. Office International Des Epizooties (OIE). Manual of Diagnostic Tests and Vaccines for Terrestrial Animals (Mammals, Birds and Bees). 6th ed. Paris: Office International Des Epizooties; 2008:712-724.

5. Tekle M. Seroprevalence of brucellosis and isolation of brucella from small ruminants that had history of recent abortion in selected Villages of Amibara district, Afar region [MSc Thesis]. Debre Zeit, Ethiopia: Faculty of Veterinary Medicine, Addis Ababa University; 2016.

6. Megid J, Mathias A, Carlos R. Clinical manifestations of brucellosis in domestic animals and humans. Open Vet. Sci. J. 2010;4 (1):119-126. doi:10.2174/1874318801004010119

7. Tesfaye A. Brucellosis in cattle and small ruminants in selected sites of Tigray Region, North Ethiopia [DVM Thesis]. Debre Zeit: FVM, AAU; 2003.

8. Shiferaw Y, Tenhagen BA, Bekena M, Kassa T. Reproductive performance of crossbred dairy cows in different production systems in central high lands of Ethiopia. Trop Anim Hlth Prod. 2003;25 (6):551-561. doi:10.1023/A:1027377722576

9. Lakew A, Hiko A, Abraha A, Hailu SM. Sero-prevalence and community awareness on the risks associated with livestock and human brucellosis in selected districts of Fafan Zone of Ethiopian-Somali National Regional State. Vet Animal Sci. 2019;7:100-147. doi:10.1016/j.vas.2019.100047

10. Yohannes M, Degefu H, Tolosa T, Belihu K, Cutler RR, Cutler SJ. Brucellosis in Ethiopia. Afr J Microbiol Res. 2013;7(14):1150-1157. doi:10.5897/AJMR12.738

11. Garoma T. Sero-epidemiology of bovine brucellosis in Horro Guduru Animal Production and Research Center, and its surroundings, Western Ethiopia [MSc Thesis]. Switzerland: Faculty of Geneva; 2018.

12. Degefa T, Duressa A, Duguma R. Brucellosis and some reproductive problems of indigenous arsi cattle in selected arsi zones of Oromia Regional State Ethiopia. Glob Vet. 2011;7(1):45-53.

13. Debassa G, Tefera M, Addis M. Small ruminant brucellosis: serological survey in Yabello District, Ethiopia. Asia J Anim Sci. 2013;7 (1):14-21. doi:10.3923/ajas.2013.14.21

14. Yohannes M, Degefu H, Tolosa T, Belihu K, Cutler R, Cutler S. Brucellosis in Ethiopia. Afr J Microbiol. 2012;7:1154-1155.

15. Gumi B, Firdessa R, Yamuah L, et al. Seroprevalence of brucellosis and Q-fever in southeast Ethiopian pastoral livestock. $J$ Vet Sci Med Diagn. 2013;2(1):1-5. doi:10.4172/2325-9590.1000109

16. DLFO. Diga district livestock and fishery development office; 2011.

17. GGLFO. Guto Gidda district livestock and fishery development office; 2011.

18. Thrusfield M. Sampling in Veterinary Epidemiology. 3rd ed. London: Black well Science Ltd.; 2007:214-256.

19. World Health Organization. Emerging and other communicable disease surveillance and control. The development of new/ improved brucellosis vaccines (Reports of the WHO Meetings, Geneva, December); 1997:1-37.

20. OIE; World Organisation for Animal Health. Bovine Brucellosis. In: Manual of Standard for Diagnostic Tests and Vaccines. 5th ed. Paris: OIE; 2004:242-262.

21. Terefe Y, Girma S, Mekonnen N, Asrade B. Brucellosis and associated risk factors in dairy cattle of eastern Ethiopia. Trop Anim Health Prod. 2017;49(3):599-606. doi:10.1007/s11250-017-1242-7
22. Degefu H, Mohamud M, Hailemelekot M, Yohannes M. Seroprevalence of bovine brucellosis in agro pastoral areas of Jijjiga zone of Somali National Regional State, Eastern Ethiopia. Ethiop Vet J. 2011;11:69-84.

23. Mekonnen H, Kalayou S, Kyule M. Serological survey of bovine brucellosis in barka and arado breeds (Bos indicus). Prev Vet Med. 2010;94(1-2):28-35.

24. Sarba EJ, Getaneh AM, Borena BM, et al. Sero-prevalence and associated risk factors of Brucellosis in dairy cattle in selected towns of West Shewa, Ethiopia. Bull Animal Health Prod Afr. 2016;64(4):387-395.

25. Asmare K, Prassad S, Asfaw Y, Gelaye E, Ayelet G, Zeleke A. Seroprevalence of brucellosis in cattle and high risk animal health professionals in Sidama Zone, Southern. Ethiop Vet J. 2007;11:69-84.

26. Bashitu L, Afera B, Tuli G, Aklilu F. Sero Prevalence study of bovine brucellosis and its associated risk factors in Debrebirhan and Ambo towns. J Adv Dairy Res. 2015;3(1):131. doi:10.4172/2329-888X.1 000131

27. Ibrahim N, Belihu K, Lobago F, Bekana M. Sero-prevalence of bovine brucellosis and its risk factors in Jimma zone of Oromia Region, South-western Ethiopia. Trop Anim Health Prod. 2010;42 (1):1006-1008. doi:10.1007/s11250-009-9382-z

28. Edao MB, Hailegebreal G, Berg S, et al. Brucellosis in the Addis Ababa dairy cattle the myths and the realities. BMC Vet Res. 2018;14 (1). doi:10.1186/s12917-018-1709-4

29. Tibesso G, Ibrahim N, Tolosa T. Sero-prevalence of bovine and human brucellosis in Adami Tulu, Central Ethiopia. World Appl Sci J. 2014;31:776-780.

30. Haileselassie M, Kalayou S, Kyule M, Asfaha M, Belihu K. Effect of Brucella infection on reproduction conditions of female breeding cattle and its public health significance in Western Tigray, northern Ethiopia. Vet Med Int. 2011;43(5):1001-1005.

31. Eticha E, Solomon H, Lemma D, Abera B. Prevalence and risk analysis of bovine brucellosis in Asella organized dairy farm, Oromia Regional State, South East Ethiopia. J Vet Med Animal Health. 2018;10(10):245-249. doi:10.5897/JVMAH2017.0558

32. Megarsa B, Biffa D, Abunna F, Regassa A, Godfroid J, Skjerve E. Seroprevalence of brucellosis and its contribution to abortion in cattle, camel, and goat kept under pastoral management in Borana, Ethiopia. Trop Anim Health Prod. 2011;43(3):651-656. doi:10.1007/ s11250-010-9748-2

33. Kebede T, Ejeta G, Ameni G. Seroprevalence of bovine brucellosis in smallholder farms in central Ethiopia (Wuchale-Jida district). Rev Méd Vet. 2008;159:3-9.

34. Dinka H, Chala R. Sero prevalence study of bovine brucellosis in pastoral and agro-pastoral areas of East Showa zone, Oromia Regional State, Ethiopia. Am Eurasian J Agric Environ Sci. 2009;6 (5):508-512.

35. Swai ES, Schoonman L. The use of rose bengal plate test to asses cattle exposure to Brucella Infection in traditional and smallholder dairy production systems of Tanga Region of Tanzania. Vet Med Int. 2010;2010:1-8. doi:10.4061/2010/837950

36. Matope G, Bhebhe E, Muma JB, et al. Sero-prevalence of brucellosis and its associated risk factors in cattle from smallholder dairy farms in Zimbabwe. Trop Anim Health Prod. 2011;43(5):975-982.

37. Mensah GI, Addo K, Aning KG, Nartey N, Nipah GK, Smits HL. Brucella abortus antibodies in raw cow milk collected from Kraals within the Coastal Savannah Zone of Ghana. J Basic Appl Sci Res. 2011;1(8):942-947.

38. Angara TE, Ismail A, Agab H, Saeed N. Sero-prevalence of bovine brucellosis in Kuku Dairy Scheme, Khartoum North, Sudan; 2004.

39. Ndazigaruye G, Mushonga B, Kandiwa E, Samkange A, Segwagwe B. Prevalence and risk factors for brucellosis seropositivity in cattle in Nyagatare District, Eastern Province, Rwanda. $J$ S Afr Vet Assoc. 2018;89:1625-1630. doi:10.4102/jsava.v89i0.1625 
40. Minda AG, Gobena A, Tesfu K, Getachew T, Angella A, Gezahegne MK. Seropositivity and risk factors for Brucella in dairy cows in Asella and Bishoftu towns, Oromia Regional State, Ethiopia. Afr J Microbiol Res. 2016;10(7):203-205.

41. Alemu F, Admasu P, Feyera T, Niguse A. Seroprevalence of Bovine brucellosis in Eastern Showa, Ethiopia. Acd J Animal Dis. 2014;3 (3):27-32.

42. Jergefa T, Kelay B, Bekana M, Teshale S, Gustafson H, Kindah H. Epidemiological study of bovine brucellosis in three agro ecological areas of Central Oromia, Ethiopia. Rev Sci Tech. 2009;28 (3):933-943. doi:10.20506/rst.28.3.1939

43. Adugna K, Agga G, Zewde G. Seroepidemiological survey of bovine brucellosis in cattle under a traditional production system in western Ethiopia 32-3 of the Scientific and Technical Review. Rev Sci Tech. 2013;32(3):765-773. doi:10.20506/rst.32.2.2218

44. Mohammed H. Seroprevalence of small ruminant brucellosis in and around Jijiga [DVM thesis]. Jimma, Ethiopia: School of Veterinary Medicine, Jimma University; 2009.

45. Berhe G, Belihu K, Asfaw Y. Seroepidemiological investigation of bovine brucellosis in the extensive cattle production system of Tigray region of Ethiopia. Int J Appl Res Vet Med. 2007;5(2):65-70.

46. Godfroid J, Saegerman C, Wellemans V, et al. How to substantiate eradication of bovine brucellosis when specific serological reaction occur in the course of brucellosis testing. Vet Microbiol. 2002;90(14):461-477. doi:10.1016/S0378-1135(02)00230-4

47. Radostitis OM, Gay CC, Hinchcliff KW, Constable PD. Veterinary Medicine. A Text Book of the Diseases of Cattle, Horses, Sheep, Pigs and Goats. Saunders Elsevier. 10th. Sydney, Toronto: Saunders Company Ltd; 2007:867-882.

48. Tolosa T. Seroprevalence study of bovine brucellosis and its public health significance in selected sites of Jimma Zone, Western Ethiopia. A thesis submitted to the Faculty of Veterinary Medicine, Addis Ababa University in partial fulfillment of the requirements for the Degree of Master of science in Tropical Veterinary Medicine; 2004:9.
49. Ataro A, Yosef D, Tadele T. Bovine brucellosis: seroprevalence and its potential risk factors in smallholder dairy farms in Hawassa Town, Southern Ethiopia, and Ethiop. Vet J. 2019;23(2):41-63. doi:10.4314/ evj.v23i2.4

50. Tolosa T, Regassa F, Belihu K. Seroprevalence Study of Bovine Brucellosis in Extensive Management System in Selected Sites of Jimma Zone, Western Ethiopia. Bull Anim Hlth Prod Afric. 2008;56:25-37.

51. Kubuafor DK, Awumbila B, Akanmori B. Seroprevalence of brucellosis in cattle and humans in the Akwapim-south district of Ghana: public health implication. Acta Trop 2000;76(1):45-48. doi:10.1016/ S0001-706X(00)00088-7

52. Asmare K, Sibhat B, Molla W, et al. The status of bovine brucellosis in Ethiopia with special emphasis on exotic and cross bred cattle in dairy and breeding farms. Acta Trop. 2013;126(3):186-192. doi:10.1016/j.actatropica.2013.02.015

53. Walker RL. Brucella. In: Hirsh DC, Zee YC, editors. Veterinary Microbiology. USA: Blackwell Science Inc.; 1999:196-203.

54. De-lahunta A, Habel R. Teeth, Applied Veterinary Anatomy. W. B. saunders company; 1986:4-6.

55. Nicholson M, Butterworth M. A Guide to Scoring of Zebu Cattle. Addis Ababa: International Livestock Centre for Africa; 1986.

56. Dinknesh T, Biniam T, Getachew K, Yifat D. Sero-prevalence of bovine brucellosis and its associated risk factors in Becho District, South West Shewa, Oromia Regional State, Ethiopia. ACR J Animal Vet Sci. 2019;5(2):35-45.

\section{Publish your work in this journal}

Veterinary Medicine: Research and Reports is an international, peerreviewed, open access journal publishing original research, case reports, editorials, reviews and commentaries on all areas of veterinary medicine. The manuscript management system is completely online and includes a very quick and fair peer-review system. Visit http://www.dovepress.com/testimonials.php to read real quotes from published authors. 